ISSN 2078-6077.

Наукові зошити історичного факультету Львівського університету. 2020. Випуск 21. С. 102-113

Proceedings of History Faculty of Lviv University. 2020. Issue 21. P. 102-113

УДК 94:[338.43-057:329.7] (477.8=162.1)"1919/1926"

\title{
ЕКОНОМІЧНІ ІНІЦІЯТИВИ В ДІЯЛЬНОСТІ ПОЛЬСЬКИХ СЕЛЯНСЬКИХ ПАРТІЙ ЗАХІДНОЇ УКРАЇНИ (1919-1926)
}

\author{
Лев КАЛИНЯК \\ Львівський національний університет імені Івана Франка \\ кафедра історичного краєзнавства \\ вул. Університетська, 1, Львів, 79000, Україна \\ e-mail: lev_ka@ukr.net
}

\begin{abstract}
Розглянуто позиції провідних польських селянських партій Західної України в питанні захисту економічних інтересів селянства. Після закінчення Першої світової та польсько-української $1918-$ 1919 рр. воєн, особливо гострими були проблеми державних кредитів на відбудову селянських господарств, відсутність будівельних матеріялів, палива, насіння тощо. На першому місці зпоміж них стояла необхідність реалізувати земельну реформу. Надання у власність селянам значної частини земельних володінь місцевих латифундистів вважалося важливою передумовою відродити село.

Ключові слова: Західна Україна, польські селянські партії, міжвоєнний період, земельна реформа, парцеляція.
\end{abstract}

Окреслена проблематика потрапляла в поле зору українських та польських дослідників селянського руху. Аналіз економічної діяльности польських селянських партій у Другій Речі Посполитій, зокрема, ставлення їхніх керівних органів до шляхів реалізації земельної реформи поданий у працях С. Макарчука, В. Смолея, 3. Баран, Ю. Р. Шафліка, А. Вензікової та 3. Томчонек‥ Разом 3 тим зазначені історики не акцентували уваги на економічних ініціятивах партійних ланок воєводського, повітового та громадського рівня, які власне і є предметом пропонованої студії.

Послідовну політику щодо захисту економічних інтересів польського селянства займало Польське Стронніцтво Людове “Пяст" (далі - ПСЛ “Пяст”) найвпливовіша польська політична партія Західної України. На початку 1920-х рр. у краю ПСЛ “Пяст" розбудувало досить потужну, як для території 3 переважальною більшістю українського населення, власну регіональну структуру. Її лідери Якуб Павловський, Ян Бриль, Анджей Вітос (рідний брат лідера ПСЛ

\footnotetext{
${ }^{1}$ Stepan Makarczuk, Wasyl Smolej, Polskie osadnictwo rolne $w$ dwudziestoleciu międzywojennym na terenach tzw. Zachodniej Ukrainy (Małopolski Wschodniej), (Chłopi Naród Kultura, Rzeszów, Wyd-wo WSP, 1997, T. 5: Chłopi a państwo). 71-82; Zoja Baran, Polityka wład polskich wobec wsi na terenie tzw. Zachodniej Ukrainy (Małopolski Wschodniej) w dwudzistoleciu międzywojennym, (Chłopi Naród Kultura, Rzeszów: Wyd-wo WSP, 1997, T. 5: Chłopi a państwo). 63-70; Józef Ryszard Szaflik, Polskie stronnictwo ludowe Piast 1926-1931. (Warszawa: LSW, 1970), 384; Alicja Więzikowa, Stronnictwo chtopskie 1926-1931. (Warszawa: LSW, 1963), 291; Zofia Tomczonek, Ruch ludowy na Kresach pótnoczno-wschodnich Drugiej Rzeczypospolitej. (Białystok: Wydawnictwo politechniki Białostockiej, 1996), 247.
} 
“Пяст”, прем’єр-міністра Другої Речі Посполитої - Віцентія Вітоса - Л.К.), Броніслав Малік та інші, у свій час були депутатами польських законодавчих органів різних скликань².

Поширенню впливів ПСЛ “Пяст”, поряд з активною роботою для того, щоб створити міцну організаційну мережу, сприяла також актуальність пропонованих діячами партії економічних гасел, що виходили з потреб місцевого польського селянства. Ефективними формами обстоювання інтересів селян були регулярно організовувані громадські віча, повітові та воєводські з'їзди, парламентська діяльність депутатів. Зміст прийнятих на них резолюцій, депутатських законопроєктів та запитів стосувався проблем селянської господарки. На першому місці з-поміж них стояла необхідність провести земельну реформу ${ }^{3}$.

Програма ПСЛ "Пяст" обстоювала ідею реалізації земельної реформи, що передбачала компенсацію землевласникам за розпарцельовані між селянами земельні наділи. Представники партії у соймі найактивніше долучилися до роботи над проєктом земельної реформи. Дня 10 липня 1919 р. сойм ухвалив проєкт “Основ земельної реформи”, запропонований ПСЛ “Пяст”. Слід зазначити, що в цьому проєкті законодавці максимально врахували інтереси польських поміщиків так званих “східних кресів”, для яких під час парцеляції визначалася найбільша норма землеволодіння - 400 га $^{4}$. Попри це, земельну реформу в Західній Україні, як в інших регіонах Польщі, так і не втілили в життя. Причиною цього стала сильна опозиція місцевих землевласників та національних демократів, які репрезентували їх політичні інтереси. Неможливість реалізувати земельну реформу іiі противники мотивували тим, що передача земельних володінь $з$ рук польських латифундистів у руки селян, переважний відсоток яких у краї становили українці, зведе до мінімуму значення польського етнічного чинника на "кресах".

Позицію землевласників та національних демократів представники місцевої організації ПСЛ "Пяст" вважали надуманою. Вони виступали проти такого розвитку подій вважаючи, що при бажанні можна легко знайти механізми, які би унеможливили такий переділ власности. Показовим із цього погляду було висловлювання лідера львівської партійної організації Я. Бриля, зроблене в жовтні 1919 р. в Самборі. Роз'яснюючи польським селянам ставлення ПСЛ "Пяст" до проведення земельної реформи, він заявив, що парцеляція у Східній Галичині повинна стояти на такій основі, щоб земля з рук польських поміщиків перейшла у власність польських селян, а - українських поміщиків - до українців ${ }^{6}$.

\footnotetext{
2 "Posłowie i senatorowie P.S.L.", Piast, 14 lutego 1923.

3 "Wiec ludowy w Winnikach", Kurjer Lwowski, 3 grudnia 1919.

${ }^{4}$ Іван Васюта, Сочіально-економічні відносини на селі Західної України до возз 'єднання (19181939), (Львів, 1978), 13-14.

${ }^{5}$ Прокурор апеляційного суду, місто Львів, Центральний державний історичний архів України у Львові (далі - ЦДІАУЛ), ф. 205, оп. 1, спр. 450, арк. 9.

6 “Z ruchu ludowego", Kurjer Lwowski, 8 października 1919.
} 
ISSN 2078-6077. Наукові зошити історичного факультету Львівського університету. 2020. Випуск 21. Proceedings of History Faculty of Lviv University. 2020. Issue 21.

Враховуючи тотальну перевагу в середовищі місцевих латифундистів етнічних поляків, можемо припустити, що така позиція передбачала істотно зміцнити позиції місцевих польських селян, а також посилити колонізацію краю цивільними та військовими колоністами 3 центральних районів Польщі цей процес було запущено в 1920 p.

Зважаючи на це, вимоги провести земельну реформу постійно стояли на порядку денному зборів ПСЛ "Пяст" у Західній Україні протягом першої половини 1919 - другої половини 1920 рр. Ухвалені резолюції закликали польський уряд негайно запровадити в дію закон від 10 липня 1919 p. ${ }^{7}$ Актуальним залишалося питання земельної реформи і після 15 липня 1920 р. Реалізацію ухваленого в той день закону “Про виконання земельної реформи” надалі стримували противники. 3 огляду на перешкоди з боку опозиції, резолюції зборів ПСЛ "Пяст" ставали дедалі жорсткішими.

Протилежне ставлення ПСЛ “Пяст” та національних демократів до реалізації земельної реформи стало причиною гострого конфлікту згаданих політичних сил у Східній Галичині. У селянському середовищі національних демократів вважали “ворогами народу і прихильниками поміщиків" став швидко наростати 3 огляду на майбутні вибори до сойму і сенату, які, як вважали представники регіональної організації ПСЛ “Пяст", мали відбутися під знаком їх протистояння з ендеками․ Його безкомпромісний характер викликав занепокоєння місцевих адміністративних органів Східної Галичини. Так, згідно зі звітами Тернопільського староства, протистояння представників ПСЛ "Пяст" та ендеків було однією із складових політичної нестабільности в регіоні ${ }^{10}$.

Вибори до парламенту 1922 р. підтвердили попереднє становище сил у польському політичному середовищі. У Східній Галичині, де ПСЛ "Пяст" сформувало власний список, партія переконливо випередила блок правих партій, до складу якого входили ендеки. На виборах до сойму в семи округах краю ПСЛ "Пяст" здобуло 209.036 голосів, що дало можливість отримати 18 депутатських мандатів ${ }^{11}$.

Одразу після виборів активізувала свою діяльність східногалицька організація ПСЛ “Пяст”. Дня 19 листопада 1922 р. у Львові відбувся регіональний Конгрес партії, у якому взяли участь депутати та сенатори від Східної Галичини. Головним на порядку денному Конгресу стояло питання захисту у парламенті представниками ПСЛ “Пяст” прав та інтересів виборців. Сприяти проведенню земельної реформи було визначене як першочергове завдання парламентського клубу ${ }^{12}$. Початок нової парламентської каденції позначився діяльністю депутатів від ПСЛ “Пяст” в округах. Протягом перших місяців 1923 р. у краї проведено

\footnotetext{
7 “Wielki wiec ludowy w Żółkwi”, Kurjer Lwowski, 2 grudnia 1919.

8 "O zniesienie pańszczyzny we wscodniej Małopolsce”, Sprawa Ludowa, 22 maja 1921.

9 “Zwycięski pochód ludowego ruchu”, Sprawa Ludowa, 11 czerwca 1922.

${ }^{10}$ Прокурор апеляційного суду, місто Львів, ЦДІАУЛ, ф. 205, оп. 1, спр. 450, арк. 8.

11 "Posłowie i senatorowie P.S.L.", Piast, 14 lutego 1923.

12 “Wielki Kongres ludowy we Lwowie”, Kurjer Ludowy, 22 listopada 1922.
} 
десятки інформаційних зборів селян, на яких депутати від партії інформували про ситуацію щодо земельної реформи ${ }^{13}$.

Питання земельної реформи залишалося актуальним надалі. У середині лютого 1924 р. Східну Малопольщу відвідав голова ПСЛ "Пяст" В. Вітос. За його участи протягом 17 - 26 лютого відбулися численні збори селян у Самборі, Мостиськах, Тернополі та Бережанах. Виступаючи перед селянами, голова ПСЛ "Пяст" окреслив пріоритетні завдання, вирішити які мала домагатися організація. Впровадити земельну реформу було першим пунктом викладеної очільником партії програми дій ${ }^{14}$.

Попри те, що в суспільстві зростала популярність радикальних гасел, щоб вирішувати цю проблему, організація надалі відкидала можливість провести парцеляцію великих землеволодінь без відшкодування. Виступаючи перед селянами, представники ПСЛ “Пяст” гостро критикували селянських радикалів, які підтримували ідею провести земельну реформу без компенсації. Реалізувати таку програму, на їхню думку, суперечило державним інтересам, оскільки несло в собі небезпеку утвердити на території Польщі більшовизм ${ }^{15}$.

Парламентарі від ПСЛ “Пяст” узяли найактивнішу участь у розробці нового проєкту земельної реформи, ініційованого 1925 р. Вагому роль у цьому відіграли депутати, які репрезентували окружну партійну організацію Східної Галичини. Від неї до соймової комісії, що працювала над проєктом земельної реформи, входили Б. Малік, Ян Навроцький та А. Вітос ${ }^{16}$. Нову редакцію закону про земельну реформу ухвалив сойм 28 грудня 1925 р. Згідно 3 цим документом, максимальний, вільний від парцеляції розмір земельного господарства становив у промислових і приміських районах 60 га, в інших регіонах - 180 га. Для східних воєводств вільний від парцеляції мінімум був визначений у 300 га. Прийнятий закон, незважаючи на свою поміркованість, надалі не мав істотного впливу на темпи реалізації земельної реформи. Парцеляція проводилася повільно, не задовільняючи потреб селянства. Так, протягом наступних років велика земельна власність загалом у Польщі зменшилася на $16 \%$, а селянська зросла на $13 \%{ }^{17}$. Регіональні організації ПСЛ "Пяст", що діяли на території Західної України, виявляли стурбованість 3 цього приводу, вимагаючи негайно впроваджувати закон про земельну реформу.

\footnotetext{
13 "Wiece i zebrania", Sprawa Ludowa, 21 stycznia 1923.

${ }^{14}$ Прокурор апеляційного суду, місто Львів, ЦДІАУЛ, ф. 205, оп. 1, спр. 435, арк. 9. 188.

${ }^{5}$ Józef Ryszard Szaflik, Polskie stronnictwo ludowe Piast 1926-1931. (Warszawa: LSW, 1970),

16 "W jakim stadium znajduje się obecnie sprawa ust. o reformie rolnej”, Sprawa Ludowa, 3 maja 1925.

17 Леонід Зашкільняк, Микола Крикун, Історія Польщі: Від найдавніших часів до наших днів, (Львів, 2002), 467.
} 
ISSN 2078-6077. Наукові зошити історичного факультету Львівського університету. 2020. Випуск 21. Proceedings of History Faculty of Lviv University. 2020. Issue 21.

Відстоюючи інтереси польських селян Західної України, ПСЛ “Пяст" вирішувало інші, важливі для цієї категорії населення проблеми економічного характеру. Так, на середину 1920-х рр. переважна більшість селянських господарств регіону перебувала в занедбаному стані. Протягом перших років існування незалежної Польської держави аграрний сектор не зміг у повному обсязі подолати труднощі, пов'язані з післявоєнною відбудовою господарства. За таких умов відновлення селянських господарств вимагало значних капіталовкладень. Місцеві організації ПСЛ “Пяст” регулярно піднімали питання необхідности надавати селянам довготермінові кредити ${ }^{18}$. Щоб прискорити механізм видачі кредиту, репрезентанти партії пропонували налагодити роботу відповідних фінансових установ - Державного рільничого банку та "Кас Стефчика" 19 .

Паралельно з вимогами надавати кредити, місцеве керівництво ПСЛ “Пяст" наполягало на необхідності зменшити податковий тиск на селянство. Партійні резолюції закликали уряд до ревізії податкової системи з тим, що запровадити для селян єдиний земельний податок ${ }^{20}$. Представники партії домагалися відтермінувати сплату податків для малоземельних селян, господарства яких зазнали матеріяльних збитків унаслідок стихійних лих ${ }^{21}$. Львівська повітова організація ПСЛ “Пяст” у середині 1924 р. піднімала питання про відміну чинного у Львові акцизу на сільськогосподарську продукцію22.

Щоб покращити матеріяльне становище селянства, ПСЛ “Пяст” пропонувало запровадити низку протекціоністських заходів. Резолюції партійних з'їздів вимагали від уряду відмінити чинні обмеження на експорт сільськогосподарської продукції та знизити ціни на ввізні промислові товари, необхідні селянам. Для забезпечення рентабельноти селянських господарств, на думку представників ПСЛ "Пяст", необхідно було також збалансувати внутрішню цінову політику щодо промислових та сільськогосподарських товарів. У зв' язку з цим регіональне керівництво організації домагалося знизити ціни на промислові товари першої необхідности та підвищити ціну на сільськогосподарську продукцію23.

Важливе місце в економічній політиці ПСЛ “Пяст” займало питання допомоги осадникам. Розпочавши процес колонізації у краю, польський уряд не міг забезпечити його достатнім фінансуванням, у результаті чого більшість осадників була позбавлена нормальних умов для організації й розвитку своїх господарств.

\footnotetext{
${ }^{18}$ Прокурор апеляційного суду, місто Львів, ЦДІАУЛ, ф. 205, оп. 1, спр. 437, арк. 14.

19 "Olbrzymi Zjazd Polskiego Stronnictwa Ludowego we Lwowie", Sprawa Ludowa, 22 marca 1925.

20 "Sprawozdanie z wiecu i Zjazdu delegatów i męzów zaufania powiatu żołkiewskiego w Zołkwi dnia 7 lutego 1926", Sprawa Ludowa, 14 marca 1926.

21 “Olbrzymi Zjazd Polskiego Stronnictwa Ludowego we Lwowie", Sprawa Ludowa, 22 marca 1925.

${ }^{22}$ Lukaszewicz. "Zebranie delegatów PSL we Lwowie”, Sprawa Ludowa, 1 czerwca 1924.

${ }^{23}$ Прокурор апеляційного суду, місто Львів, ЦДІАУЛ, ф. 205, оп. 1, спр. 438, арк. 15.
} 
Уперше питання польського осадництва у Західній Україні представники ПСЛ “Пяст" підняли на скликаному ними у січні 1922 р. Першому великому з'їзді осадників, що відбувся у Львові. З’їзд, до президії якого ввійшли Я. Павловський, Б. Малік, А. Вітос, окреслив нагальні проблеми осадників, а також жорстко критикував урядовців, відповідальних за реалізацію програми колонізації ${ }^{24}$. Вимоги допомогти осадникам мали місце у пунктах резолюцій згадуваних партійних з'їздів 4-го та 5-го червня 1922 р. та регіонального Конгресу 19 листопада $1922 \mathrm{p}^{25}$.

Підвищену активність у справі допомоги осадникам та організації осадницького руху ПСЛ “Пяст” виявляло протягом 1923 р. Так, на початку року питання фінансової допомоги цій категорії селян на засіданні сойму підняв Я. Бриль. У відповідь на його запит парламентська аграрна комісія постановила виділити для цих потреб 12 мільярдів марок ${ }^{26}$. Протягом року ПСЛ "Пяст" організовувало низку повітових та воєводських з'їздів осадників. Зокрема, 31 травня в Тернополі відбувся з'їзд осадників Тернопільського і Збаразького повітів, участь у якому взяло 250 делегатів із 33 осад. Подібні акції відбулися у Скалаті, Чорткові, Раві-Руській та Бережанах ${ }^{27}$. Наприкінці серпня - на початку вересня воєводські з'їзди осадників пройшли у Станиславові та Львові ${ }^{28}$. Їх проведення створило сприятливі умови для організації у краю центрального координаційного органу польського осадництва. Відтак, 9 вересня 1923 р. на так званому Конгресі осадників Східної Малопольщі, за присутности голови ПСЛ "Пяст" В. Вітоса, обрали Головну управу Союзу Осадників. До ії складу увійшли провідні діячі місцевої організації ПСЛ “Пяст”: головою управи став Ян Драч, віце-головами - Б. Малік, Ян Дескур, скарбником - Ян Бляйке ${ }^{29}$.

Проблеми осадників регулярно піднімала партійна преса ПСЛ "Пяст". Трибуною польських колоністів була “Sprawa Ludowa”. На іï сторінках з'явилася окрема рубрика “Dziat osadniczy” (Осаднищький розділ), постійними ведучими якої були А. Вітос, та Леон Хабаловський - голова осадничого відділу при Малопольському рільничому товаристві. Подібна рубрика - " $Z \dot{z} y c i a$ osadników” (3 життя осадників), велася на сторінка "Всі Волиньскей”.

До травневого перевороту 1926 р. в польському селянському русі в Західній Україні домінувала поміркована політична течія, що іiі репрезентувало ПСЛ "Пяст". В опозиції до цієї організації перебували представники лівих та радикальних селянських партій, які підтримували ідею кардинальної зміни земельного устрою Другої Речі Посполитої. Радикальний селянський рух краю

24 “Naglące potrzeby osadników w Małopolsce wsch”, Sprawa Ludowa, 12 lutegî 1922.

25 "Rezolucje Kongresu P.S.L.", Kurjer Ludowy, 23 listopada 1922.

26 "Poseł Bryl wywalczył dla osadników kresowych 12 miljardów”, Wola Ludu, 25 marca 1923.

${ }^{27}$ Chabałowski L. "Zjazdy osadników”, Sprawa Ludowa, 10 czerwca 1923.

28 "III-ci Zjazd Wojewódskich Osadników we Lwowie", Sprawa Ludowa, 9 września 1923.

29 “Kongres Osadników Małopolski Wschodniej we Lwowie”, Sprawa Ludowa, 16 września1923. 
ISSN 2078-6077. Наукові зошити історичного факультету Львівського університету. 2020. Випуск 21. Proceedings of History Faculty of Lviv University. 2020. Issue 21.

підтримував ідею провести земельну реформу без викупу поміщикам за розпарцельовані у них земельні наділи. Ї̈ репрезентували Польське Стронніцтво Людове “Лівиця” (далі - ПСЛ “Лівиця”), Союз Хлопський, Незалежна Партія Хлопська (далі - НПХ). Значна кількість радикально настроєного селянства краю була об'єднана також у лівій селянській партії Польське Стронніцтво Людове "Визволєнє” (далі - “Визволєнє")

Біля джерел польського радикального селянського руху в Західній Україні стояло ПСЛ “Лівиця”. Його створив у 1913 р. один із лідерів селянського руху в Галичині Ян Стапінський і воно виражало інтереси найбіднішого селянства краю ${ }^{30}$. Основною програмною вимогою партії, яка свідчила про радикальні настрої іiі керівництва, було проведення земельної реформи через примусову парцеляцію великих землеволодінь без викупу ${ }^{31}$. Згадана політична організація не змогла створити серйозної конкуренції ПСЛ "Пяст" і до 1924 р. зійшла 3 політичної арени краю. Прихильники ПСЛ “Лівиця” перейшли до інших політичних партій та угруповань, що стояли на засадах радикально вирішувати земельне питання.

У своїй політичній діяльності ПСЛ “Визволєнє” постійно еволюціонувало в бік радикального селянського руху. До 1923 р. організація виступала за якомога швидшу реалізацію земельної реформи на основі закону від 10 липня 1919 р. ${ }^{32}$ Але після довгого зволікання з його вирішенням у партії почали набирати популярности ідеї кардинальної зміни чинного земельного устрою Польщі. Значна частина депутатів та членів ПСЛ “Визволєнє” перейшла на радикальні позиції, вимагаючи запровадити таку земельну реформу, яка б не передбачала грошової компенсації поміщикам за конфісковані у них земельні надлишки ${ }^{33} .3$ цього приводу виникла жвава внутрішньопартійна дискусія на сторінках друкованого органу партії - тижневика "Визволєнє".

Тоді ж депутати парламентського клубу ПСЛ “Визволєнє” розпочали готувати власний проєкт земельної реформи. На початку квітня 1924 р. новий проєкт під назвою "Закон про виконання земельної реформи або запровадження нового земельного устрою в Речі Посполитій” репрезентували в соймі. Згідно з ним, поміщицькі володіння мали обмежуватися 30-ма га у промислових районах та 60-ма га у сільській місцевості. Земельні надлишки за відшкодування переходили у власність держави і мали бути розпарцельовані між малоземельними селянами ${ }^{34}$.

${ }^{30}$ Stanisław Lato, Ruch ludowy a Centrolew, (Warszawa, 1965), 14.

${ }^{31}$ Stanisław Lato, Witold Stankiewicz, Programy stronnictw ludowych. Zbiór dokumentów, (Warszawa, 1969), 161.

32 "Głos ludu", Wyzwolenie, 2 grudnia 1923.

${ }^{33}$ Niedzielski T. "Bez odszkodowania! ”, Wyzwolenie, 23 marca 1924.

${ }^{34}$ Malinowski M. "Nasz projekt reformy rolnej”, Wyzwolenie, 20 kwietnia 1924. 
Від травня 1924 р. ідею провести земельну реформу на основі цього проєкту активно пропагували на території Західної України депутати сойму від ПСЛ “Визволєнє”. Особливою активністю відзначалася діяльність В. Войтовича, який протягом травня - червня 1924 р. організував партійні збори у кількох громадах Теребовлянського повіту ${ }^{35}$. Основною вимогою ухвалених на них резолюцій було проводити земельну реформу на основі проєкту ПСЛ "Визволєнє". Подібна вимога містилася в резолюціях, схвалених 6 липня 1924 р. згаданим з'їздом делегатів ПСЛ “Визволєнє” від Східної Галичини ${ }^{36}$.

Половинчастий характер запропонованого проєкту не задовільняв частину радикально настроєних членів партії. У 1924 р. у ПСЛ “Визволєнє" відбувся розкол, у результаті якого створено НПХ. Нова селянська організація почала виступати за радикальне проведення земельної реформи. Впливи НПХ швидкими темпами поширилися на Поліссі. Тут у 1925 р. до НПХ перейшла значна частина членів ПСЛ “Визволєнє”з7.

Протягом 1924 р. радикальні погляди щодо методів проведення земельної реформи домінували і серед членів ПСЛ “Визволєнє”, які залишилися вірними своїй організації. Остаточно з цього питання партія визначилася на початку 1926 p. В ухваленій 15 березня на Загальному з'їзді ПСЛ “Визволєнє” програмі визначалася необхідність відчужувати без відшкодування усі поміщицькі та церковні маєтки на користь селян ${ }^{38}$. У Західній Україні провести земельну реформу на декларованих партійною програмою засадах певний час агітувала Волинська Окружна організація ПСЛ “Визволєнє”з".

Створений у 1924 р. на основі ПСЛ “Лівиця” Союз Хлопський у своій діяльності виступав як класова селянська партія, покликана захищати інтереси селянства. Головне завдання організації - забезпечити населенню кращі умови економічного і культурного розвитку. Виходячи з цього, проблему реалізації земельної реформи представники Союзу Хлопського вважали за необхідне вирішити в радикальний спосіб. Згідно з партійною програмою, земля повинна була належати тим, хто на ній працює. Тому великі поміщицькі маєтки, а також церковні землі, мали вилучати у їх власників на користь селян без відшкодування ${ }^{40}$.

Ідею проводити земельну реформу на таких засадах пропагували на всіх масових заходах, організованих Союзом Хлопським в Західній Україні. Так, виступаючи 12 жовтня 1924 р. на зборах селян, скликаних повітовою управою у

${ }^{35}$ Urząd Wojewódski Tarnopol, Archiwum Akt Nowych w Warszawie (далі - AAN), zespół. Urząd Wojewódski Tarnopol (далі - UWÒ), sygn. 982 / 2, k. 89, 91.

36 "Dla dobra państwa i ludu", Kurjer Lwowski, 10 lipca 1924.

${ }^{37}$ Zofia Tomczonek, Ruch ludowy na Kresach pólnoczno-wschodnich Drugiej Rzeczypospolitej. (Białystok: Wydawnictwo politechniki Białostockiej, 1996), 69.

38 "Nasz Walny Zjazd", Wyzwolenie, 22 marca 1925.

39 Волинське воєводське правління, Державний архів Волинської області (далі - ДАВО), ф. 46, оп. 9 а, спр. 159, арк. 10.

${ }^{40}$ Stanisław Lato, Witold Stankiewicz, Programy stronnictw ludowych. Zbiór dokumentów, (Warszawa, 1969), 218. 
ISSN 2078-6077. Наукові зошити історичного факультету Львівського університету. 2020. Випуск 21. Proceedings of History Faculty of Lviv University. 2020. Issue 21.

Львові, Тадеуш Геллєр зазначив, що проведення земельної реформи на основі конфіскації великої земельної власности без відшкодування не повинно бути образою для поміщиків, а лише відновлювати соціяльну справедливість. Свою позицію щодо методів проводити земельну реформу висловили делегати Окружного з'їду Союзу Хлопського, що відбувся 25 січня 1925 р. у Львові. Звинувативши в гострій формі політику, яку зайняли в цьому питанні уряди В. Вітоса та Владислава Грабського, вони декларували необхідність вилучати велику земельну власність без викупу ${ }^{41}$.

Регіональна організація Союзу Хлопського домагалася вирішувати інші актуальні для селян проблеми економічного та політичного характеру. Зокрема, для ефективного розвитку селянські господарства потребували значних капіталовкладень. У зв'язку з цим резолюції партійних зборів вимагали надати селянам низьковідсоткові кредити. Покращенню ситуації щодо цього могла сприяти також децентралізація Земельного банку. Тому представники Союзу Хлопського з метою прискорити отримання кредиту, виступали за необхідність творити філії цієї фінансової установи в кожному повітовому центрі краю ${ }^{42}$.

Місцеве керівництво партії наполягало також зменшити податковий тиск на селян. Зокрема, воно виступало за повну відміну податку з майна для осадників. На початку 1926 р. окружна організація Союзу Хлопського у Львові провела масову акцію протесту проти магістратського акцизу на сільськогосподарську продукцію43.

Щоб покращити матеріяльне становище селянства, Союз Хлопський пропонував запровадити низку протекціоністських заходів. Організація виступала за відміну чинних обмежень на експорт сільськогосподарської продукції за кордон, а також запропонувала зменшити ціни на імпортовані промислові товари, необхідні дрібним селянським господарствам ${ }^{44}$.

Вирішення назрілих економічних проблем у Союзі Хлопському розглядали в контексті необхідности зміни вищого державного керівництва Польщі. Партійні резолюції вимагали реально залучити до вищої виконавчої влади Ю. Пілсудського - політика, якого селяни вважали єдиною альтернативою дискредитованим урядам "Гієно-Пясту", здатного, на їхню думку, вирішити основну проблему, пов’язану із швидкою реалізацією земельної реформи. Реорганізації мала підлягати й вища законодавча влада. Представники Союзу Хлопського виступали за створення однопалатного парламенту, а також за відміну інституції державного виборчого списку до вищих законодавчих органів, як такого, що суперечить духу демократії ${ }^{45}$.

${ }^{41}$ Прокурор апеляційного суду, місто Львів, ЦДІАУЛ, ф. 205, оп. 1, спр. 433, арк. 74.

42 "Zebranie lwowskiego Zarządu Powiatowego Zw. Chłopskiego", Sprawa Ludowa, 17 lipca 1924.

43 "Masowy wiec chłopski”, Sprawa Chłopska, 7 lutego 1926.

${ }^{44}$ Urząd Wojewódski Tarnopol, AAN, UWT, sygn. 982 / 2, k. 85.

45 “Okręgowy Zjazd Związku Chłopskiego we Lwowie”, Sprawa Chłopska, 8 lutego 1925. 
Причини посилення радикальних тенденцій у селянському середовищі регіону крилися головно в економічній площині. Зубожіння села, спричинене скрутним фінансовим становищем у державі та небажанням офіційної влади сприяти реалізації земельної реформи, переконало найбільш незахищену частину селян рішуче обстоювати свої інтереси. Утворені в результаті цього на території краю нові польські селянські політичні угруповання вимагали радикально розв' язати земельне питання. ПСЛ “Пяст" надалі послідовно обстоювало ідею поміркованого підходу до вирішення головного питання економіки села. Щоправда, відкидаючи популістські заклики радикалів, партія до травневого перевороту 1926 р. втратила частину впливів серед селянства Західної України на користь своїх політичних опонентів.

\title{
ECONOMIC INITIATIVES IN ACTIVITY OF POLISH PEASANT PARTIES OF WESTERN UKRAINE (1919-1926)
}

\author{
Lev KALYNYAK \\ Ivan Franko National University of Lviv \\ Department of Local History \\ Universytetska str. 1, 79000, Lviv, Ukraine \\ e-mail: lev_ka@ukr.net
}

Different positions of the leading Polish peasant parties of Western Ukraine in the matter of peasants' economic interests defense became the main issues of this article. The most influent Polish political party of Western Ukraine Polske Stronnitsvo Lyudove "Pyast" (PSL "Pyast") took a consistent policy in question of the Polish peasants' economic interests' defense. At the beginning of 1920 the Party built very strong local structure, which was really powerful for the region with the majority of Ukrainian population. The actual, formed at the needs of local Polish peasants economic mottos, were spread by party' leaders through the strong organizational network. The strong structure and really actual mottos increased the influence of PSL "Pyast" in the region. The regular public meetings, congresses, parliament activity of deputies became the most effective forms of peasants' interests lobbing. Problems of peasants' household were the main issues of adopted resolutions, laws and deputy requests. The necessity of land reform implementation was the most important among them. PSL "Pyast" program supported the idea of land reform implementation in the sense of prediction of compensation to land owners for the parceling of land allotments among peasants.

PSL "Pyast" proposed some protectoral measures, which supposed to improve material position of peasants. The resolutions of party congresses demanded from the government to cancel acting limitations for agricultural production export and to decrease prices for import industrial goods, needed by peasants. The representatives of PSL "Pyast" for the purpose of agricultural households' profitability supplying also supported the idea of the necessity to balance the domestic price policy for industrial and agricultural goods. According to this the regional leaders of organization required lower prices for industrial goods of the first necessity and higher prices for agricultural product.

Left and radical peasant parties, which support the idea of deep changes of the Polish land system, formed the opposition to PSL "Pyast". The radical peasant movement demanded the land reform implementation without financial compensation to land owners for the parceling of land allotments among peasants. The reasons of the radical trends intensification in the peasant' regional community 
ISSN 2078-6077. Наукові зошити історичного факультету Львівського університету. 2020. Випуск 21. Proceedings of History Faculty of Lviv University. 2020. Issue 21.

concerned mainly the economic sphere. Village pauperization, caused by difficult financial situation in the state and reluctance of the official government to promote the land reform implementation, convinced the most unprotected part of peasants in the necessity of radical defense of their interests. As the result new polish peasant political groups, which advocated for radical solution of land question, were created. PSL "Pyast" continued to support the idea of moderate approach for solution of the main question of village economic. Rejection of populist mottos, popularized by radicals, had the consequences for PSL "Pyast". At the period of May Revolution of 1926 the Party lost some influence among peasants of Western Ukraine for its political opponents.

Keywords: Western Ukraine, Polish peasant parties, interwar period, land reform, parceling

\section{REFERENCES}

Alicja Więzikowa, Stronnictwo chłopskie 1926-1931. (Warszawa: LSW, 1963), 291.

Archiwum Akt Nowych w Warszawie, Zespół. Urząd Wojewódski Tarnopol, Sygnatura 982 / 2. Chabałowski L. "Zjazdy osadników”, Sprawa Ludowa, 10 czerwca 1923.

“Dla dobra państwa i ludu”, Kurjer Lwowski, 10 lipca 1924.

"Głos ludu”, Wyzwolenie, 2 grudnia 1923.

Ivan Vasuta, Socialno-ekonomichni vidnosyny na seli Zahidnoii Ukrainy do vozjednannia (1918-1939), (Lviv, 1978), 13-14.

Józef Ryszard Szaflik, Polskie stronnictwo ludowe Piast 1926-1931. (Warszawa: LSW, 1970), 384.

"Kongres Osadników Małopolski Wschodniej we Lwowie", Sprawa Ludowa, 16 września1923.

leonid Zashkilnyak, Mykola Krykun, Istoriya Polshchi. Vid naydavnishykh chasiv do nashykh dniv. (Lviv, 2002), 467. (in Ukrainian)

Malinowski M. "Nasz projekt reformy rolnej”, Wyzwolenie, 20 kwietnia 1924.

"Masowy wiec chłopski”, Sprawa Chłopska, 7 lutego 1926.

"Naglące potrzeby osadników w Małopolsce wsch", Sprawa Ludowa, 12 lutego 1922.

"Nasz Walny Zjazd”, Wyzwolenie, 22 marca 1925.

Niedzielski T. "Bez odszkodowania! “, Wyzwolenie, 23 marca 1924.

"O zniesienie pańszczyzny we wscodniej Małopolsce”, Sprawa Ludowa, 22 maja 1921.

“Okręgowy Zjazd Związku Chłopskiego we Lwowie”, Sprawa Chłopska, 8 lutego 1925.

"Olbrzymi Zjazd Polskiego Stronnictwa Ludowego we Lwowie", Sprawa Ludowa, 22 marca 1925.

"Poseł Bryl wywalczył dla osadników kresowych 12 miljardów”, Wola Ludu, 25 marca 1923.

“Posłowie i senatorowie P.S.L.”, Piast, 14 lutego 1923.

"Sprawozdanie z wiecu i Zjazdu delegatów i mężów zaufania powiatu żołkiewskiego w Zołkwi dnia 7 lutego 1926”, Sprawa Ludowa, 14 marca 1926.

Stanisław Lato, Ruch ludowy a Centrolew, (Warszawa, 1965), 14.

Stanisław Lato, Witold Stankiewicz, Programy stronnictw ludowych. Zbiór dokumentów, (Warszawa, 1969), 161.

Stepan Makarczuk, Wasyl Smolej, Polskie osadnictwo rolne $w$ dwudziestoleciu międzywojennym na terenach tzw. Zachodniej Ukrainy (Małopolski Wschodniej), (Chłopi Naród Kultura, Rzeszów, Wyd-wo WSP, 1997, T. 5: Chłopi a państwo). 71-82.

"W jakim stadium znajduje się obecnie sprawa ust. o reformie rolnej", Sprawa Ludowa, 3 maja 1925.

“Wielki Kongres ludowy we Lwowie”, Kurjer Ludowy, 22 listopada 1922. 
ISSN 2078-6077. Наукові зошити історичного факультету Львівського університету. 2020. Випуск 21. Proceedings of History Faculty of Lviv University. 2020. Issue 21.

“Wiec ludowy w Winnikach”, Kurjer Lwowski, 3 grudnia 1919.

"Wiece i zebrania", Sprawa Ludowa, 21 stycznia 1923.

"Wielki wiec ludowy w Żółkwi”, Kurjer Lwowski, 2 grudnia 1919.

“Z ruchu ludowego", Kurjer Lwowski, 8 października 1919.

"Zebranie delegatów PSL we Lwowie”, Sprawa Ludowa, 1 czerwca 1924.

"Zebranie lwowskiego Zarządu Powiatowego Zw. Chłopskiego", Sprawa Ludowa, 17 lipca 1924.

Zofia Tomczonek, Ruch ludowy na Kresach północzno-wschodnich Drugiej Rzeczypospolitej. (Białystok: Wydawnictwo politechniki Białostockiej, 1996), 247.

Zoja Baran, Polityka wład polskich wobec wsi na terenie tzw. Zachodniej Ukrainy (Małopolski Wschodniej) w dwudzistoleciu międzywojennym, (Chłopi Naród Kultura, Rzeszów: Wyd-wo WSP, 1997, T. 5: Chłopi a państwo). 63-70.

“Zwycięski pochód ludowego ruchu”, Sprawa Ludowa, 11 czerwca 1922.

"III-ci Zjazd Wojewódskich Osadników we Lwowie”, Sprawa Ludowa, 9 września 1923. 